\title{
Correction to: Accuracy-dominance and conditionalization
}

\section{Michael Nielsen ${ }^{1}$}

\section{Correction to: Philos Stud https://doi.org/10.1007/s11098-020-01598-6}

The article Accuracy-dominance and conditionalization, written by Michael Nielsen, was originally published online on the publisher's internet portal on 09 March 2021 with Open Access under a Creative Commons Attribution (CC BY) license 4.0.

With the author's decision to cancel Open Access the copyright of the article changed on 11 August 2021 to $\odot$ The Author(s), under exclusive licence to Springer Nature B.V. part of Springer Nature 2021 with all rights reserved.

The original article has been updated.

Publisher's Note Springer Nature remains neutral with regard to jurisdictional claims in published maps and institutional affiliations.

The original article can be found online at https://doi.org/10.1007/s11098-020-01598-6.

Michael Nielsen

michael.nielsen@sydney.edu.au

1 The University of Sydney, Sydney, Australia 